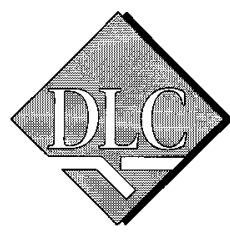

\title{
ODP Leg 163, South-East Greenland volcanic rifted margin
}

\author{
Hans Christian Larsen, Robert S. Duncan, James F. Allan \\ and ODP Leg 163 shipboard party
}

The South-East Greenland margin is a type example of a volcanic rifted margin. The margin is characterised by a broad seaward-dipping reflector sequence (SDRS) composed of basalt that onlaps continental (mainly Precambrian) crust to the west and terminates eastward in oceanic crust of early Tertiary age (Figs 1,2 ). In the North-East Atlantic, seafloor-spreading anomalies $24 \mathrm{n}-24 \mathrm{r}$ are the oldest identified pair of anomalies (Talwani \& Eldholm, 1977; Srivastava \& Tapscott, 1986; Larsen, 1988). Anomaly 24n is developed off South-East Greenland as a double-peaked anomaly, reflecting the three short positive events C24n.1 to $\mathrm{C} 24 \mathrm{n} .3$ and relatively high spreading rates during this interval (approximately $3 \mathrm{~cm} / \mathrm{yr}$ half-rate; Larsen, 1980).

The minimum age of the South-East Greenland SDRS is constrained by the seaward occurrence of well developed seafloor-spreading anomalies (Fig. 1; Larsen \& Jakobsdóttir, 1988). In the north, close to the Iceland-Greenland Ridge, the SDRS extends seaward to chrons C22n-C21n (49-47 Ma). However, most of the South-East Greenland SDRS is found landward of and is older than C24n.1 (53 Ma; Cande \& Kent, 1992). Weak and semilinear magnetic anomalies are present over the main SDRS and may represent either low-amplitude anomalies older than $\mathrm{C} 24 \mathrm{n}$ (e.g., C25n-C27n, 56-61 Ma) or short magnetic events within C24r (the chryptochrons of Cande \& Kent, 1992; see also Larsen et al., 1994a, plate 2, fig. 7).

Evidence for significant magmatism and tectonism during continental breakup is not restricted to the offshore areas. A coast-parallel dyke swarm and associated seaward flexuring of the crust are present from latitude $63^{\circ} \mathrm{N}$ along the East Greenland coast and northward. Within this zone, gabbroic and syenitic intrusions are present (Fig. 1; Myers, 1980; Myers et al., 1993) and locally associated with basaltic lavas overlying thin sediments (for review see Larsen, 1980; Nielsen et al., 1981; Brooks \& Nielsen, 1982). Farther north, a thick and much more extensive flood basalt province is preserved (Fig. 1; Larsen et al., 1989). Comprehensive studies of the onshore region (see also Brooks et al., this report) are being conducted in parallel with Ocean Drilling Program (ODP) drilling and will be augmented in 1996 with a programme of deep crustal seismic imaging that includes the region from the central Iceland Greenland Ridge to south of Greenland (Fig. 1;
Larsen et al., 1995; Larsen, this report). In particular, ODP drilling and field geological studies will aim at correlating the onshore and offshore parts of the crustal flexure zone and the volcanic stratigraphy within the two areas.

Drilling was positioned along two margin transects, located distal (Legs 152 and 163) and proximal (Leg 163) to the Iceland plume centre. The two transects were named EG63 and EG66, respectively, in reference to their approximate latitudes. At each transect, drilling was targeted at the pre-rift crust, the breakup unconformity and earliest volcanism, the transition from initial continental volcanism to ocean crust volcanism and, most seaward, a reference hole in steady-state spreading crust. This drilling strategy was designed (Larsen et al., 1991) with two primary objectives: (1) investigation of the development with time along each transect would clarify the progressive weakening of the continental crust and the associated magmatic development; and (2) the study of magmatic development and the magma source at different offsets from the Iceland plume in order to evaluate possible radial zonation in the original plume structure. Additional reference points for the second objective are provided by the earlier Deep Sea Drilling Project (DSDP) Leg 81 drilling at the Hatton Bank (Fig. 1; Joron et al., 1984) and ODP Leg 104 drilling at the Vøring margin (intermediate northern offset; Viereck et al., 1988; see also Larsen et al., 1994a).

\section{Background and operations}

\section{Geophysical database}

Legs 152 and 163 were planned on the basis of extensive seismic data over the South-East Greenland margin (Fig. 2). The database comprises three different sets of seismic data: (1) regional to detailed grids of shallow, highresolution multichannel seismic (MCS) data (Larsen et al., 1994b); (2) a regional grid of deep 7 seconds (two way. traveltime, TWT) MCS data (Larsen, 1990); and (3) deep 14 seconds (TWT) MCS data (Larsen et al., 1995). In addition, aeromagnetic and regional marine gravity data exist (for a more extensive review and references see Larsen $e t$ al., 1994a). 




Fig. 1. Geological map of the North Atlantic showing the distribution of seaward dipping reflector sequences, fracture zones (GFZ, JMFZ), ocean floor ridges (JMR) and continental flood basalts of the North Atlantic volcanic province. ODP and DSDP drill sites along the volcanic rifted margins of the North Atlantic are shown. Subaerially erupted basalts show flood basalt structure landward of the inferred continent/ocean boundary and have a SDRS structure seaward of the boundary. IGR: Iceland-Greenland Ridge.

\section{Leg 152: results and implications for Leg 163}

A number of important observations made during Leg 152 drilling (EG63 Transect on Fig. 1) into the South-East Greenland SDRS significantly affected the detailed planning of Leg 163. These include the following: (1) the occurrence of highly tilted to subvertical pre-rift sediments below the inner part of the SDRS; (2) that early, continentally hosted and contaminated basaltic to andesitic vol- canic rocks of 61-62 Ma age (Sinton et al.; 1994) overlie these sediments; (3) that the upper limit of these lower lavas is a sharp transition - possibly a hiatus - into picritic to tholeiitic lavas, followed by basalts of uniform composition that resemble depleted tholeiites from Iceland and appear to make up the main part of the SDRS; and (4) that all recovered igneous units were erupted subaerially. Thus, Leg 152 confirmed that the SDRS is a wedge of predominantly basaltic material extruded subaerially in accord with the 


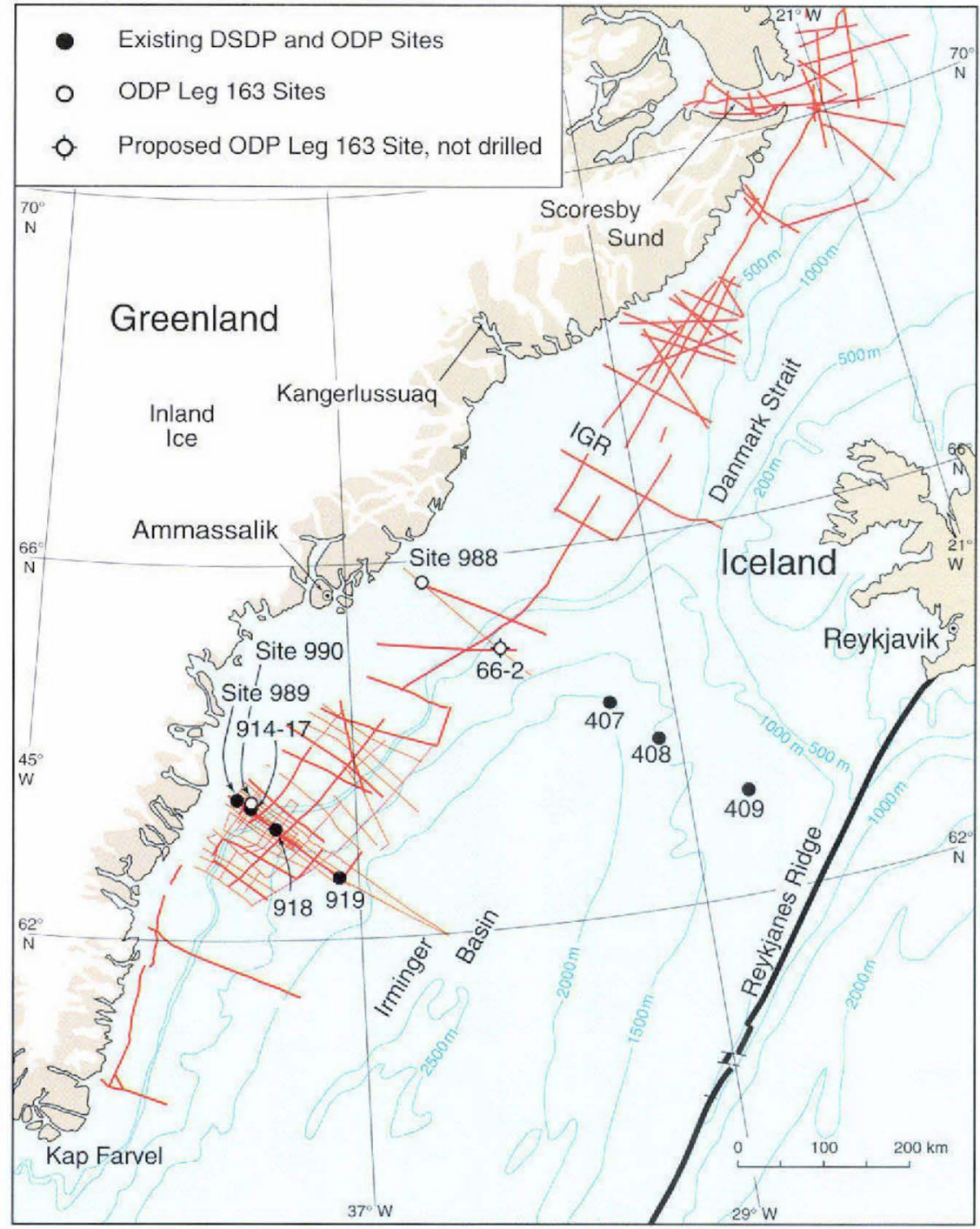

Fig. 2. Seismic track map and regional bathymetry. Previously drilled holes and Leg 163 drilled sites and planned sites are shown. IGR: Iceland-Greenland Ridge. model for crustal accretion in Iceland (Pálmason, 1986) and with the interpretation of seismic data (Mutter et al., 1982; Larsen \& Jakobsdóttir, 1988).

The findings during Leg 152 imply the presence of a rapid transition from continental to oceanic crust below the inner part of the SDRS. During formation of this continent to ocean transition, pre-rift sediments were deposited in a basin of unknown width and, later, in a zone close to the final line of breakup, subjected to faulting and crustal extension, uplift and erosion prior to volcanism (see also Larsen et al., 1994a).

The Leg 152 data are not adequate in a number of aspects: suitable material for age determination of the oceanic succession (i.e. the main part of the SDRS) is lacking, the sampling of the transition from initial picritic to depleted tholeiitic volcanism within the oceanic succession is non- continuous, and the oldest part of the continental volcanic succession has not been recovered. In addition, the pre-rift sediments were poorly sampled because of their subvertical orientation, and they have been too strongly metamorphosed to yield any age-diagnostic microfossils or palynomorphs.

Leg 163 was planned to overcome these deficiencies within the southern EG63 transect, as well as to sample the break-up and early seafloor spreading volcanism in a more proximal position to the proposed Iceland 'hot spot' track along the northern EG66 transect. The faint signature of the Iceland plume in the Leg 152 rocks suggests that a stronger plume imprint could be present at this location closer to the former plume axis, which if true, would indicate a radial zonation within the original plume structure. 

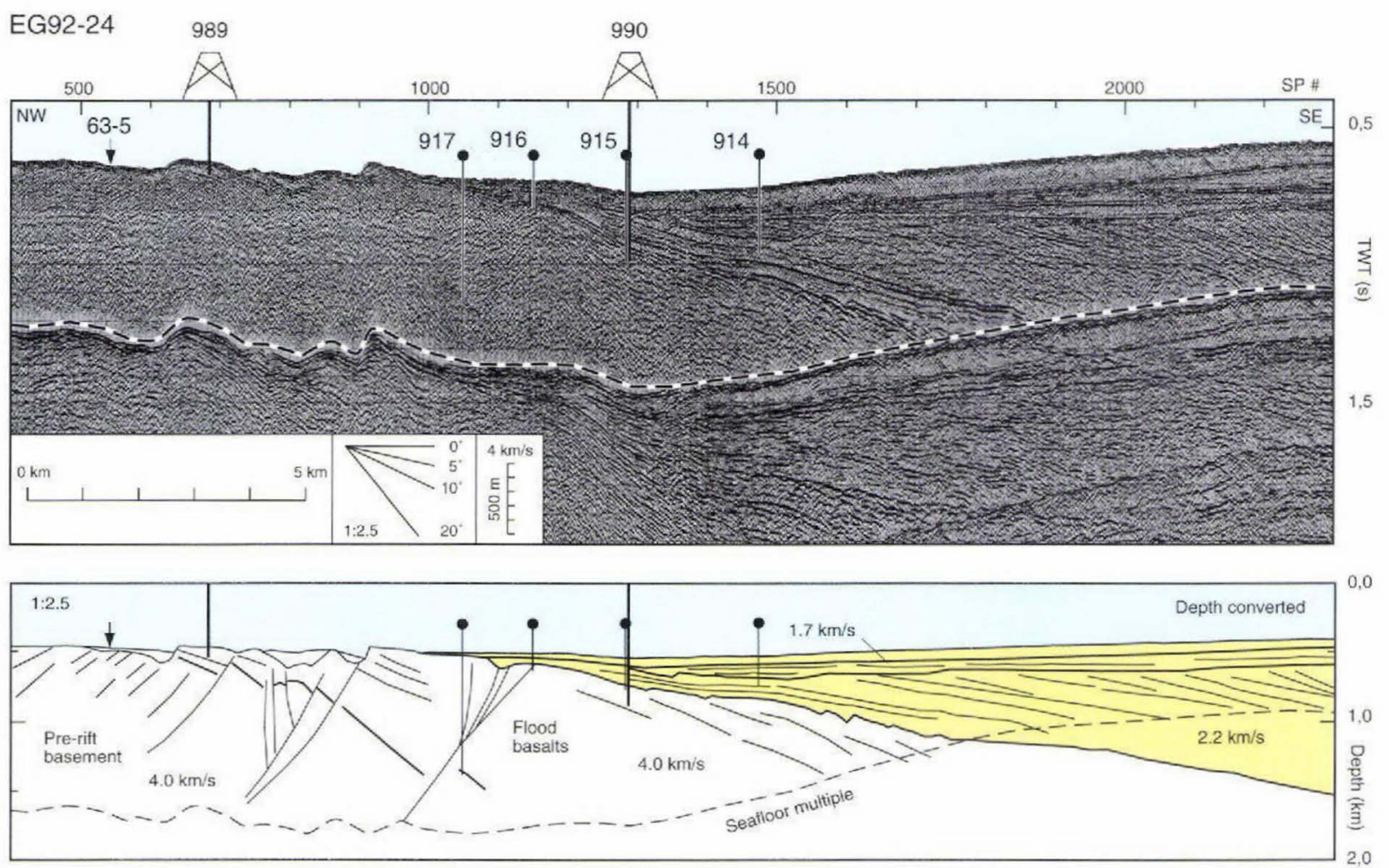

Fig. 3. Seismic cross-section through Site 989 (top). Interpretations shown in line drawing (middle) and migrated interpretation (bottom). Steeply dipping to subvertical pre-rift sediments were encountered within the rotated fault block located below the lava sequence at Site 917. ODP Sites 914-917 are described in Larsen et al. (1994a). Planned Site EG63-5 designed to sample the pre-rift crust (sediments?) was not drilled.

Integration of observations from drilling, field geology, and geophysics on crustal structure and deformation, timing of volcanism and the involvement of Iceland plume material in the break-up process, will eventually enable a critical review of current models of plume structure and the impact of mantle plumes on the process of continental break-up (e.g., Mutter et al., 1988; White \& McKenzie, 1989; Richards et al., 1989; Campbell \& Griffiths, 1990; Coffin \& Eldholm, 1992; Kent et al., 1992; Holbrook \& Keleman, 1993).

\section{Drilling plan}

In order to meet the main objectives, six first-priority sites were planned for the two transects. Three sites were planned for the innermost part of the EG63 transect. Two sites were targeted to increase the sampling of the pre-rift crust and oldest volcanic cover, and one site was to deepen Site 915 in order to provide stratigraphic overlap with Site 917 (Figs 2, 3). Three sites were also planned for the northern EG66 transect (Figs 2, 4). The two sites within the innermost part had objectives roughly similar to the inner sites of the EG63 transect, although less ambitious in terms of stratigraphic coverage. The additional seaward site was planned in SDRS-type oceanic crust of anomaly 22 age (i.e. in steady-state accreting Icelandic-type oceanic crust). Along the EG66 Transect already existing DSDP Sites 406-408 (Fig. 2) would extend the transect into Miocene and younger ocean crust.

\section{Operations and changes in the drilling plan imposed by drilling problems and weather}

The cruise started from Reykjavik on 7 September 1995 and was scheduled to end in Halifax, 27 October. However, early in the cruise the drill-rig was damaged during shallow water coring, and later in the cruise extreme storm conditions damaged the ship and forced an early termination of the cruise. As a result of these events the scientific drilling operations at Leg 163 were reduced to less than one-half of the planned programme.

Recoil from a break in the drill pipe on 10 September damaged the top-drive assembly after only one day of drilling at the first, shallow-water site at the northern EG66 Transect (Site 988; Figs 2, 4). A port call to Reykjavik, Iceland, was made in order to make the necessary re- 


\section{Line EG93-20}
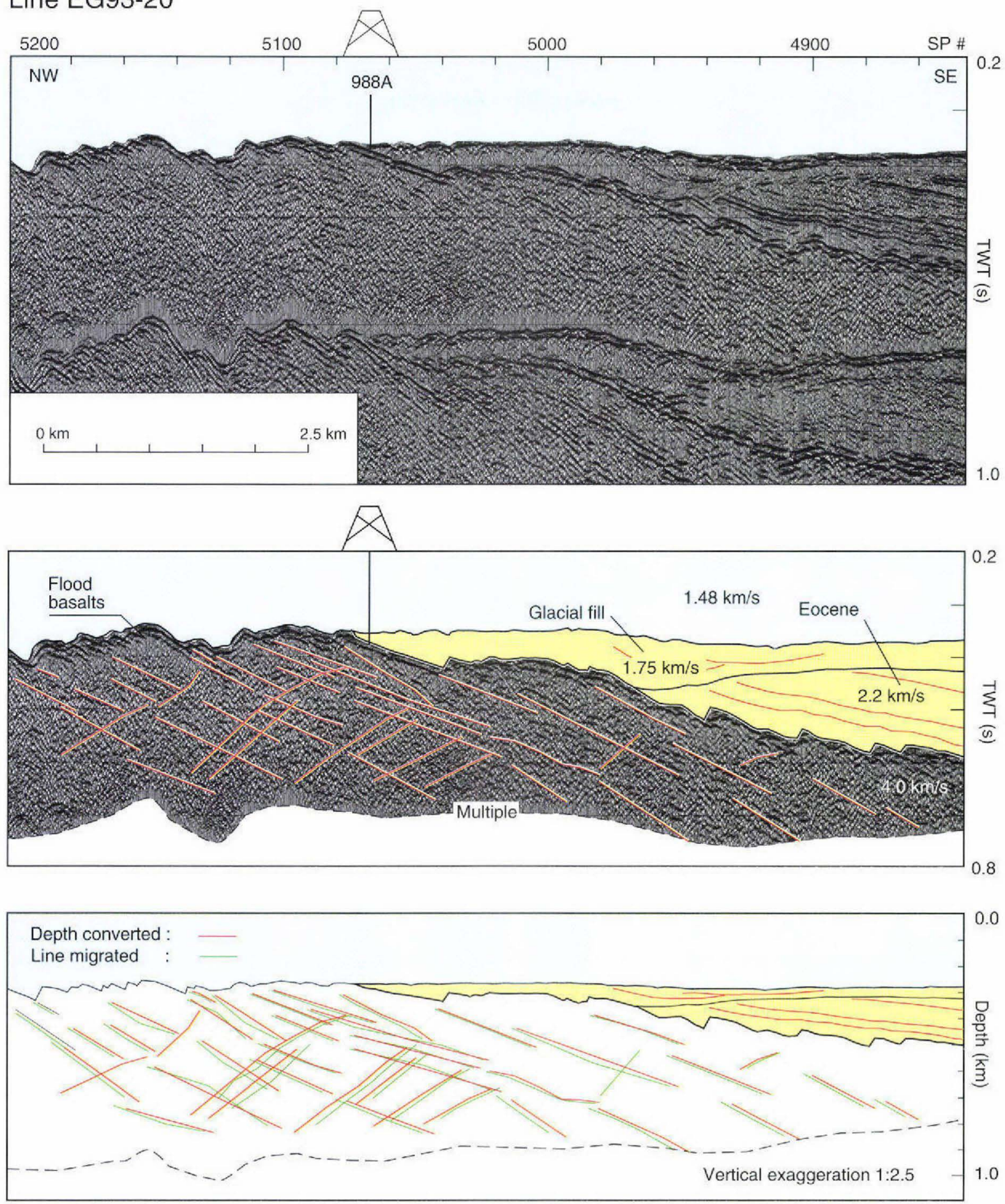

Fig. 4. Seismic cross-section (top) through Site 988 at the EG66 transect. Interpretations shown in line drawing (middle) and migrated section (bottom). The Eocene age of the post-rift sediments is inferred by correlation with the EG63 transect (Larsen et al., 1994a). Two more sites were planned for this transect (landward and seaward of Site 988; not shown), but were not drilled. 


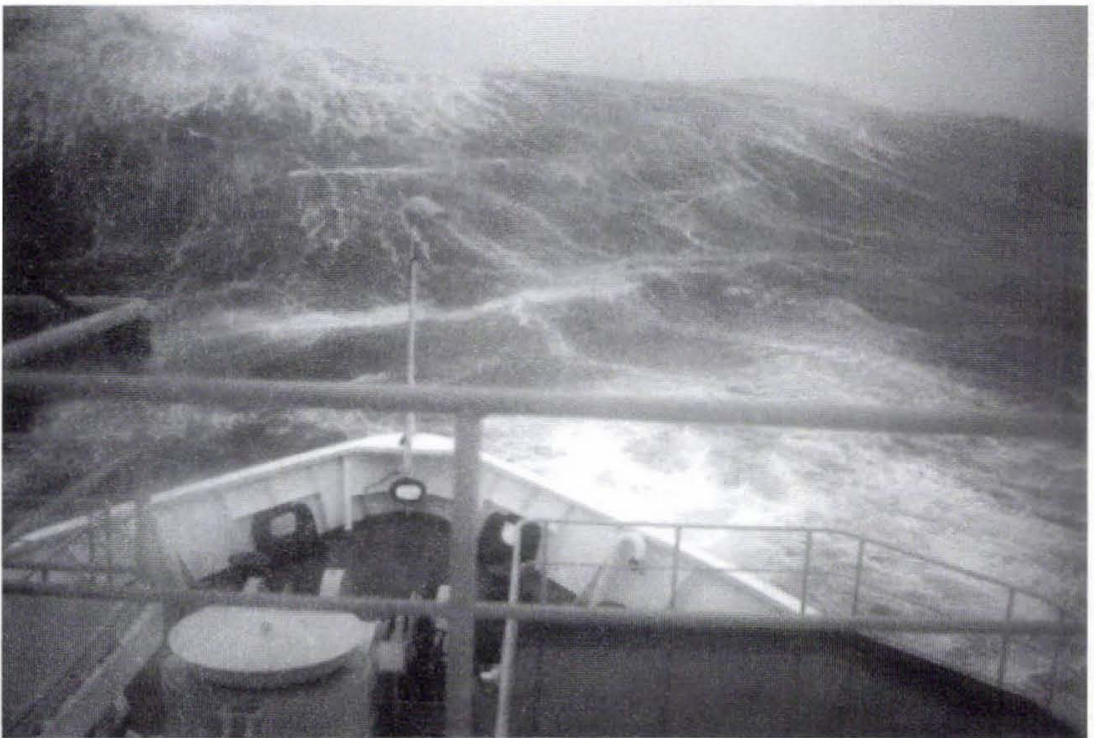

Fig. 5. View from the bridge of the drill ship JOIDES Resolution during the hurricane on 30 September 1995. Bridge level is at approximately $10 \mathrm{~m}$ height. The waves were estimated to be at least $20 \mathrm{~m}$ high, and shore based analysis of video-tapes suggested that some waves approached $30 \mathrm{~m}$ height. pairs. Permission to drill in water depths shallower than $300 \mathrm{~m}$ was temporarily withdrawn by the operator of ODP, Texas A\&M University, pending review of safety procedures and the delivery of supplementary drilling hardware. Operations therefore resumed at the deeper water sites along the southern EG63 transect on 16 September. Drilling progressed (Sites 989 and 990; Fig. 3), with interruptions due to heavy seas and icebergs drifting across the drill sites, until 29 September.

Extreme hurricane conditions built up rapidly through the night of 29 September. At this time Site 990 was almost drilled to target depth, and preparations for re-occupying and deepening Site 989 were made. However, the wind speed continued to increase and at many times it exceeded 100 knots from north-north-east, and remained at hurricane force for at least 26 hours (extra-tropical hurricane force 2). By the morning of 30 September, the ship was being battered by steep short-period waves, more than $20 \mathrm{~m}$ high, and she was unable to maintain position without risking severe damage (Fig. 5). The ship's bridge took water through a broken window, which caused both radars to fail and threatened the computers controlling the dynamicpositioning system. Numerous thrusters were mechanically damaged or became inoperable because of flooding. In spite of reduced maneuverability, the ship was able to maintain heading in the wind and sea while being forced southwards at a speed of up to 4 knots with an increased potential of colliding with icebergs. When the storm abated to gale force on 1October, the ship turned southwards en route to Halifax, Nova Scotia, for repairs. As a result of these untimely events, only three of the planned six sites were drilled.

\section{Drilling results}

\section{Site 988}

Site 988 is located $56 \mathrm{~km}$ east of the East Greenland coast, within the northern drilling transect EG66 (Figs 2, 4). The site was selected to penetrate deeply into the feather-edge of the SDRS that overlies the transition zone between continent and ocean crust. The primary drilling objectives at this site were to determine the composition, age and eruption environment of the SDRS in a position close to the Iceland-Greenland Ridge for comparison with the distal SDRS cored during Leg 152. Hole 988A was drilled in this location, but only to shallow depth $(32 \mathrm{~m}$ below seafloor; mbsf) where the drill-pipe became stuck and broke.

A thin layer ( $0-10 \mathrm{mbsf}$ ) of Quaternary (?) glaciomarine sediments unconformably overlie basaltic basement (igneous units 1 and 2). The glaciomarine sediments include rounded cobbles of gabbro, fine-grained granite, aphyric basalt, and gneiss. Compacted diamicton was not recovered at this site.

Two igneous flow units were recognised in the core recovered from the interval 10-32 mbsf. Igneous unit 1 is a plagioclase-pyroxene-olivine-phyric basalt. Only the lower contact was recovered; the thickness of the unit is between 19 and $21 \mathrm{~m}$. The unit has a massive aspect, is sparsely vesicular and shows alteration of the glassy groundmass and the sparse olivine phenocrysts. Igneous unit 2 (29-32 mbsf) is, by contrast, highly to completely altered.

Shipboard X-ray fluorescence (XRF) data show that both units have high $\mathrm{Nb} / \mathrm{Zr}(0.12)$ and $\mathrm{Ce} / \mathrm{Y}(1.2)$ ratios, identical to Tertiary basalts from Iceland (Fig. 6). The low Ni 
content and low $\mathrm{Mg} \#$ of igneous unit 1 (about 74 ppm and 0.50 , respectively) are consistent with the evolved threephase phenocryst assemblage of this basalt. Both units were most likely emplaced as lava flows, but the absence of an upper contact in Unit 1 means that we cannot eliminate the remote possibility that it is a sill. The highly oxidised aspect of unit 2 is consistent with emplacement as a flow in a subaerial environment.

The relative enrichment in incompatible elements seen at Site 988 (Fig. 6) is consistent with the pattern of enrichment along the present day Reykjanes Ridge (Schilling, 1982) and within late Tertiary ocean crust south of Iceland (DSDP sites 406-408; see Fig.2)

Palaeomagnetic data for basalts at Site 988 were obtained using the shipboard cryogenic magnetometer. The core has a consistent reversed polarity with two exceptions. One normal polarity reading was probably caused by two pieces of core being inverted during labelling and splitting. Another interval of normal polarity is located in the highly altered clay-rich flow top material of unit 2 immediately below the bottom of igneous unit 1 . The magnetic orientation of this material was probably affected by the high degree of secondary alteration observed, or possibly by the drilling process.

\section{Site 989}

Site 989 is located about $40 \mathrm{~km}$ east of the East Greenland coast. It is one of the three drill sites planned for the southern drilling transect EG63 (Figs 2, 3). Drilling at Leg 152, Sites 915 and 917 , penetrated a thick lava sequence that recorded development from early continental lithosphere (crust?)-contaminated volcanism, through transitional picritic and tholeiitic volcanism contemporaneous with break-up, into oceanic volcanism. Site 989 was selected to penetrate and sample the very oldest lavas of the SDRSs that overlie the breakup unconformity and underlying, layered pre-rift crust, possibly pre-rift sediments. The primary drilling objectives at this site were: (1) to determine the stratigraphy, composition, age, and eruption environment of the volcanic rocks above the break-up unconformity; (2) to determine the nature and age of the break-up unconformity; and (3) to determine the nature and deformation of the continental basement and/or prerift sediments beneath the volcanic sequence. Two holes, $989 \mathrm{~A}$ and $\mathrm{B}$ were drilled at this location.

A thin layer (0-4 mbsf) of Quaternary(?) glaciomarine sediments unconformably overlies the basaltic basement (igneous units 1 and 2). The only material recovered consists of discrete rock fragments, including gneiss, aphyric basalts/ metabasalts, quartzite and dolerite; fine-grained sediments were not recovered. The relatively easy penetration of the sediments at Site 989 suggests that these are glaciomarine



Fig. 6. N-MORB normalised (Sun \& McDonough, 1989) minorelement and trace-element spidergrams of cored basalts from the SDRS along the EG66 transects (Site 988) and EG63 (Sites 915, 917,918, 989. and 990). The Site 917 data include only samples with $6 \%-9 \% \mathrm{MgO}$; samples with high $\mathrm{Nb} / \mathrm{Zr}$ were excluded. The fields for basalts from Sites 917 and 918 are based on data in Larsen et al. (1994a) and Fitton et al. (in press). The Site 988 lavas are similar to Tertiary basalts from Iceland and Scoresby Sund, East Greenland (Larsen et al., 1989; Fitton et al., in press) and are considerably enriched in incompatible elements compared to the lavas the EG63 transect.

deposits, rather than overcompacted glacial tills.

Two igneous flow units were recognised in the core recovered from the interval 4-84 mbsf (Hole 989B). From seis- 
mic data, these are indicated to lie stratigraphically below the lavas drilled at Site 917 and represent the oldest part of the SDRS.

Igneous unit 1 is at least $69 \mathrm{~m}$ thick, the thickest lava flow yet reported from a SDRS. The top of the flow was not recovered. Unit 1 is essentially aphyric. The groundmass consists of plagioclase, augite, magnetite, trace olivine and mesostasis. Clay alteration is total for both mesostasis and olivines, whereas plagioclases and augites are generally fresh. It is characterised by uniform grain size, uniform vesicularity, high mesostasis content and repeated bands showing quench textures. These features indicate rapid cooling during solidification throughout emplacement of the entire lava flow. Unit 1 is interpreted as a compound lava flow consisting of numerous individual sub-units $0.1-10 \mathrm{~m}$ thick. The large number of thin sub-units, together with the absence of sharp flow contacts, may indicate both proximity to the eruptive vent and rapid eruption of the entire lava flow. An upward decrease in the maximum sub-unit thickness within igneous unit 1 may reflect diminishing eruption rate with time during deposition of this large flow.

Igneous unit 2 is at least $11 \mathrm{~m}$ thick, but the lower boundary was not penetrated. It is very massive, porphyritic with phenocrysts of plagioclase, augite, and trace olivine in a very fine-grained matrix. Olivine phenocrysts occur as individual disseminated grains that are now totally altered to clay. Plagioclase and augite phenocrysts are fresh, commonly strongly zoned and resorbed (plagioclase), and in glomerocrystic clusters.

The two igneous units recovered at Site 989 are both strongly depleted in a number of incompatible elements such as $\mathrm{Zr}, \mathrm{Nb}$, Ti and $\mathrm{P}$ and presumably derived from a depleted mantle source (Fig. 6). Both lava flows are composed of evolved basalt, which implies storage in a magma chamber underlying this part of the volcanic succession. Similar crustal magma chambers were invoked for the lavas in the Lower Series at Site 917, but these are enriched in $\mathrm{Sr}$ and $\mathrm{Ba}$, probably because of assimilation of a crustal component (Larsen et al., 1994a; Fitton et al., in press). The low $\mathrm{Sr}$ and $\mathrm{Ba}$ contents in the Site 989 lavas preclude a direct correlation with the lower series in Site 917 located only $4 \mathrm{~km}$ in down-dip direction.

Unit 1 recovered in both sites 988 and 989 appears to carry a normal magnetic polarity. If confirmed, this will be the first flow of normal polarity reported from the East Greenland margin. Unit 2 appears to contain both normal (top) and reversed magnetic polarity. The top part of the flow was possibly remagnetised during the emplacement of the normally magnetised unit 1 . Confirmation of the magnetic polarity must await further alternating field and thermal demagnetisation studies.

\section{Site 990}

Site 990 is located about $50 \mathrm{~km}$ east of the East Greenland coast, within the southern drilling transect EG63. It was one of three drill sites planned to complete the stratigraphic sampling of the earliest volcanism along this margin (Figs 2,3). The site was located at the position of previous ODP Site 915 in order to penetrate more deeply into the lava succession (only one lava flow unit was recovered in Hole 915A). By expanded stratigraphic sampling it would be possible to test the hypothesis that Iceland-type oceanic crustal accretion and steady-state production of Icelandtype tholeiites were initiated within this stratigraphic interval as indicated by the Hole 915 lava. Another important objective at this site was to sample material suitable for precise radiometric and magnetostratigraphic age determination in order to assess the length of a suspected hiatus in volcanic activity located between the middle and upper series lavas at Site 917. One hole, Hole 990A was drilled very close to Site 915 to a total depth of $325 \mathrm{mbsf}$.

Because the sedimentary section had been cored at Site 915 during Leg 152, Site 990 was washed to a depth of $182.0 \mathrm{mbsf}$ and rotary cored below that level. Sediments were recovered in the interval 182.0-202.3 mbsf and subdivided into two lithologic units termed lithologic unit I and lithologic unit II. The ages of these are unknown, but the ages of the overlying sediment and underlying basalt at Site 915 suggest an early Eocene age (Larsen et al., 1994a).

Lithologic unit $\mathrm{I}$ is a calcite-cemented mixed-cobble conglomerate, dominated by clasts of altered basalt, gabbro, and dolerite; quartzite and siliciclastic siltstone form the remainder of the cobbles. The cobbles are generally rounded to well rounded and range in size from 4 to $>12 \mathrm{~cm}$ in diameter. The matrix is a poorly sorted silty sand, with angular grains, sand-sized mudstone intraclasts and calcite cement.

Lithologic unit II directly overlies basalt and is a clayey volcaniclastic breccia, dominated by basaltic debris. Clasts in the breccia are predominantly angular and composed of dark yellowish brown, altered basaltic material. The sedimentological data suggests that unit I was deposited in a high-energy environment, possibly a high-gradient stream, a shallow, wave-influenced marine setting or a fan delta.

Additional sedimentary material, apparently not transported, was recognised as red, brecciated to clayey material on the tops of flow units within the basalt basement.

Thirteen volcanic flow units were recognised below the sedimentary units and down to 325 mbsf. Flows were identified on the basis of changes in phenocryst assemblage or the presence of weathered or vesicular flow tops. Lava flows fall into one of three types: aa, pahoehoe, and transitional. Pahoehoe flows dominate in the lower part of 
the drilled sequence, whereas aa flows are ubiquitous in the upper portion. The top of the volcanic section at this site (and the previously drilled Site 915 ) is deeply weath ered and oxidised, indicating that eruption occurred subaerially with some time gap between successive flow units.

Flow units cored at Site 990 range from aphyric to highly olivine or plagioclase-olivine-clinopyroxene-phyric basalt. The olivine content decreases upwards in the section, whereas both grain size and flow thickness increase upwards. There is a subtle but systematic compositional variation in trace-element content from the base to the top of the sequence (i.e. decreasing $\mathrm{Cr}$ and $\mathrm{Ni}$ and increasing $\mathrm{V}$, $\mathrm{Nb}, \mathrm{Zr}$ and $\mathrm{Y}$ ). In general, the lavas are moderately evolved with low trace-element abundances, and are geochemically similar to the single unit recovered from Site 915 and all units at Site 918 (72 km to the east; Fig. 6). Lavas similar to the upper series cored at Site 917 (3 km to the west) were not found, indicating that the transition from the break-up related series to the Iceland-type tholeiitic series that dominates the oceanic SDRS is abrupt and occurs over a stratigraphic interval of $<100 \mathrm{~m}$ (seismic correlation in Fig. 3).

Palaeomagnetic data for the basalts from Site 990 suggests the presence of a magnetic reversal between two normally magnetised flows at the top of the drilled section and the lower 11 reversely magnetised flows. This finding of a magnetic reversal may have significant chronostratigraphic importance and needs confirmation by onshore laboratory work.

\section{Conclusions}

Despite the significant loss of operational time because of drilling problems, weather conditions and consequent ship damage, extraordinary high recovery of core at three critical sites provided the material to address several of the high-priority objectives of the leg. However, the main tectonic objective of drilling through the break-up unconformity and sampling the pre-rift crust (presumably sediments) was not fulfilled. Likewise, the important objective of extensive sampling of the rift volcanism close to the Iceland hot spot track (EG66 transect) was only very briefly addressed. The following are the initial, major results of the cruise:

- A virtually complete record of the volcanic evolution of the East Greenland margin at latitude $63^{\circ} \mathrm{N}$ now exists. This includes the earliest, depleted and continentally contaminated, relatively deeply segregated magmas, through break-up related picritic and tholeiitic magmas derived by shallower and larger degrees of melting, to a steady-state oceanic magma series.
- Two magnetic polarity reversals, the first ever recorded from early Tertiary age volcanic materials of East Greenland, have been preliminary identified; in addition fresh, feldspar-phyric flow units suitable for radiometric dating have been recovered. These findings offer the promise of a detailed and precise time scale for the volcanic activity during break-up.

- The geochemical data indicate that Iceland mantle plume component is more strongly expressed in the compositions of basalts at latitude $66^{\circ} \mathrm{N}$ compared with $63^{\circ} \mathrm{N}$. Together with evidence from DSDP Leg 81 (Hatton Bank, Rockall Plateau) and ODP Leg 104 (Vøring Plateau), significant information on the basic compositional structure of the mantle melting regime that existed during the initiation of the Iceland plume and break-up of the North Atlantic has now been collected.

Acknowledgements. The crew on board the ODP drill ship JOIDES Resolution is thanked for outstanding committment to scientific drilling and for professional seamanship during the extreme weather conditions encountered during ODP Leg 163. The site survey for ODP Leg 163 was funded by the Danish Natural Research Council.

\section{References}

Brooks, C. K. \& Nielsen, T. F. D. 1982: The East Greenland continental margin: a transition between oceanic and continental magmatism. J. geol. Soc. Lond. 139, 265-275.

Campbell, I. H. \& Griffiths, R. W. 1990: Implications of mantle plume structure for the evolution of flood basalts. Earth Planet. Sci. Lett. 99, 79-93.

Cande, S. C. \& Kent, D. V. 1992: A new geomagnetic polarity time scale for the Late Cretaceous and Cenozoic. J. Geophys. Res. 97, 13917-13951.

Coffin, M. F. \& Eldholm, O. 1992: Volcanism and continental break-up: a global complication of large igneous provinces. In Storey, B. C., Alabaster, T. \& Pankhurst, R. J. (ed.) Magmatism and the causes of continental break-up. Spec. Publ. geol. Soc. Lond. 68, 17-30.

Eldholm, O., Thiede, J., Taylor, E. \& ODP shipboard party 1989: Proc. ODP, Scientific Results, Leg 104. College Station, Texas: Ocean Drilling Program. $1141 \mathrm{pp}$.

Fitton, J. G., Saunders, A. D., Larsen, L. M., Hardarson, B. S. \& Norry, M. J. in press: Volcanic rocks from the East Greenland margin at $63^{\circ} \mathrm{N}$ : composition, petrogenesis and mantle sources. In Saunders, A. D. et al. (ed.) Proc. ODP, Init. Repts. 163. College Station, Texas: Ocean Drilling Program.

Holbrook, W. S. \& Keleman, P. B. 1993: Large igneous province on the US Atlantic margin and implications for magmatism during continental breakup. Nature 364, 433-436.

Joron, J. L., Bougault, H., Maury, R. C., Bohn, M. \& Desprairies, A. 1984: Strongly depleted tholeiites from the Rockall Plateau margin, North Atlantic: geochemistry and mineralogy. In Roberts, D. G. et al. (ed.) Init. Repts. DSDP. 81, 783-794. Washington: U.S. Government Printing Office, 
Kent, R. W., Storey, M. \& Saunders, A. D. 1992: Large igneous provinces: sites of plume impact or plume incubation? Geology 20, 891-894.

Larsen, H. C. 1980: Geological perspectives of the East Greenland continental margin. Bull. geol. Soc. Denmark 29, 77-101.

Larsen, H. C. 1988: A multiple and propagating rift model for the Northeast Atlantic. In Morton, A. C. \& Parson, L. M. (ed.) Early Tertiary volcanism and the opening of the northeast Atlantic. Spec. Publ. geol. Soc. Lond. 39, 157-158.

Larsen, H. C. 1990: The East Greenland Shelf. In Grantz, A., Johnson, L. \& Sweeney, J. F. (ed.) The Arctic Ocean region. The geology of North America L, 185-210. Boulder, Colorado: Geological Society of America.

Larsen, H. C. \& Jakobsdóttir, S. 1988. Distribution, crustal properties and significance of seawards-dipping sub-basement reflectors off East Greenland. In Morton, A. C. \& Parson, L. M. (ed.) Early Tertiary volcanism and the opening of the northeast Atlantic. Spec. Publ. geol. Soc. Lond. 39, 95-114.

Larsen, H. C., Sawyer, D. S. \& NARM-DPG 1991: North Atlantic rifted margins detailed planning group report. JOIDES J. 3, 24-26.

Larsen, H. C., Saunders, A. D., Clift, P. \& ODP shipboard party 1994a: Proc. ODP, Init. Repts. 152. College Station, Texas: Ocean Drilling Program. 977 pp.

Larsen, H. C., Saunders, A. D., Larsen, L. M., Lykke-Andersen, H., Leg 152 Scientific Party, Marcussen, C. \& Clausen, L. 1994b: ODP activities on the South-East Greenland margin: Leg 152 drilling and continued site surveying. Rapp. Grønlands geol. Unders. 160,75-81.

Larsen, H. C., Brooks, C. K., Hopper, J. R., Dahl-Jensen, T., Pedersen, A. K., Nielsen, T. D. F. \& field parties 1995: The Tertiary opening of the North Atlantic: DLC investigations along the east coast of Greenland. Rapp. Gronlands geol. Unders. 165, 106-115.

Larsen, L. M., Watt, W. S. \& Watt, M. 1989: Geology and petrology of the lower Tertiary plateau basalts of the Scoresby Sund region, East Greenland. Bull. Gronlands geol. Unders. 157, 164 pp.

Mutter, J. C., Talwani, M. \& Stoffa, P. L. 1982: Origin of seaward-dipping reflectors in oceanic crust off the Norwegian margin by "subaerial sea-floor spreading." Geology 10, 353357.

Mutter, J. C., Buck, W. R. \& Zehnder, C. M. 1988: Convective partial melting. 1. A model for the formation of thick basaltic sequences during the initiation of spreading. J. Geophys. Res. B93, 1031-1048.

Myers, J. S. 1980: Structure of the coastal dyke swarm and associated plutonic intrusions of East Greenland. Earth Planet. Sci. Lett. 46, 407-418.

Myers, J. S., Gill, R. C. O., Rex, D. C. \& Charnley, N. R., 1993. The Kap Gustav Holm Tertiary plutonic centre, East Greenland. J. geol. Soc. Lond. 150, 259-276.

Nielsen, T. F. D., Soper, N. J., Brooks, C. K., Faller, A. M., Higgins, A. C. \& Matthews, D. W. 1981: The pre-basaltic sediments and the Lower Basalts at Kangerdlugssuaq, East Greenland: their stratigraphy, lithology, palaeomagnetism and petrology. Meddr. Gronland, Geosci. 6, 25 pp.
Pálmason, G., 1986: Model of crustal formation in Iceland, and application to submarine mid-ocean ridges. In Vogt, P. R. \& Tucholke, B. E. (ed.) The western North Atlantic region. The geology of North America M, 87-98. Boulder, Colorado: Geological Society of America.

Richards, M. A., Duncan, R. A. \& Courtillot, V. E. 1989: Flood basalts and hot-spot tracks: plume heads and tails. Science $\mathbf{2 4 6}$, 103-107.

Roberts, D. G., Schnitker, D. \& ODP shipboard party 1984. Init. Repts. Deep Sea Drill Program 81. Washington: U.S. Government Printing Office. 923 pp.

Schilling, J.-G., Meyer, P. S., \& Kingsley, R. H. 1982: Evolution of the Iceland hotspot. Nature 296, 313-320.

Sinton, C. W., Larsen, H. C. \& Duncan, R. A. 1994: The timing of the volcanism at the SE Greenland margin, ODP Leg 152. Eos 75, 607 only.

Srivastava, S. P. \& Tapscott, C. R. 1986: Plate kinematics of the North Atlantic. In Vogt, P. R. \& Tucholke, B. E. (ed.) The western North Atlantic region. The Geology of North America $\mathbf{M}$. 379-404. Boulder, Colorado: Geological Society of America.

Sun, S.-S. \& McDonough, W. F. 1989: Chemical and isotope systematics of oceanic basalts: implications for mantle composition and processes. In Saunders, A. D. \& Norry, M. J. (ed.) Magmatism in the ocean basins. Spec. Publ. geol. Soc. London 42, 313-345.

Talwani, M. \& Eldholm, O. 1977: Evolution of the NorwegianGreenland Sea. Geol. Soc. Amer. Bull. 88, 969-999.

Viereck, L. G., Taylor, P. N., Parson, L. M., Morton, A. C., Hertogen, J. \& ODP shipboard party 1988: Origin of the Palaeogene Vøring Plateau volcanic sequence. In Morton, A. C. \& Parson, L. M. (ed.) Early Tertiary volcanism and the opening of the northeast Atlantic. Spec. Publ. geol. Soc. London 39, 69-83.

White, R. S. \& McKenzie, D. P. 1989: Magmatism at rift zones: the generation of volcanic continental margins and flood basalts. J. Geophys. Res. 94, 7685-7730.

\section{OPD Leg 163 scientific party}

H. C. Larsen and R. S. Duncan (co-chief scientists), J. F. Allan (ODP staff scientist), Y. Aita, N. T. Arndt, C. J. Bücker, H. Cambray, K. V. Cashman, B. P. Cerney, P. D. Clift, J. G. Fitton, P. R. Hooper, S. D. Hurst, L. A. Krissek, K. E. Kudless, L. M. Larsen, B. Le Gall, C. E. Lesher, Y. Nakasa, Y. Niu, H. Philipp, S. Planke, J. Rehacek, A. D. Saunders, D. A. H. Teagle and C. Tegner.

\section{H. C. L., Danish Lithosphere Centre, Copenhagen}

R. S. D., College of Oceanography, Oregon State University, Oceanography Administration Building 104, Corvallis, Oregon 97331-5503, USA

J. F. A., Ocean Drilling Program, 1000 Discovery Drive, Texas A\&M University Research Park, College Station, Texas 778459547, USA 